\title{
Microencapsulation of Rice Bran Oil by Spray Drying and its Application in Producing High Quality Yoghurt
}

\author{
Nahed, M. M. Atta ${ }^{1}$, Ahmed, M. Abo khashaba ${ }^{1}$, Omayma, E. Shaltout ${ }^{2}$, \\ Hisham, A. Abd El -lateaf ${ }^{3}$, Entisar, A. El-Difrawy ${ }^{2}$
}

\begin{abstract}
The present study aimed to evaluate microencapsulated rice bran oil as a potential source of bioactive compounds and to utilize it in preparing functional yoghurt. Rice bran oil (RBO) was extracted from rice bran as a by-product by hydraulic press. RBO was encapsulated by spray-drying with wall materials such as maltodextrin (MD): Whey protein concentrate (WPC), MD:WPC: gum arabic (GA) and MD:GA at ratios (3:2), (3:1:1) and (3:2), respectively. The ratios between rice bran oil (RBO) (core) and coating materials were 1:2 and 1:4. Physico-chemical characteristics and bioactive compounds were measured in RBO. The stability, particle size distribution and zeta potential of emulsion were evaluated; also encapsulation efficiency (EE) and surface morphology of capsules powder were studied. Encapsulated rice bran oil (ERBO) was used to fortify yoghurt. Physico-chemical properties (pH value, acidity and WHC) and organoleptic properties were determined during storage periods (zero time, 7 and 14 days) on the fortified yoghurt and control. The study revealed that, the mixture wall material with MD: GA at ratio 3:2 and core: coating materials at ratio 1:4 were found to be the best effective on emulsion stability $(\mathbf{1 0 0 \%})$ with no separation phase, particle size distribution $(249.8 \mathrm{~nm}$.), zeta potential $(-31.49 \mathrm{mV})$. Use of MD: GA as a wall material with core to coat material at ratios 1:4 for encapsulation of $\mathrm{RBO}$ caused a decreased in the surface oil content $(0.22)$ and an increase in EE $(78 \%)$. The particles of capsules powder obtained from MD: GA at 3:2 ratio with core to coat material at ratios $1: 2$ and 1:4 are smooth spheres with little appendages and no cracks or fissures. Adding powder of ERBO at different concentrations (2, 4 and 6\%) and RBO at $2 \%$ to yoghurt samples caused a decrease in $\mathbf{p H}$ and increase in values of acidity and WHC during the storage period. According to the results obtained, there were changes in values of organoleptic parameters of control and different tested levels of supplemented yoghurt samples with RBO and ERBO during the storage periods, these changes were still within the acceptable scores and satisfaction panelists.
\end{abstract}

Keywords: Rice bran oil, physico-chemical characteristics, fatty acid composition, bioactive compounds, microencapsulation and organoleptic properties.

DOI: 10.21608/ASEJAIQJSAE.2020.86055

${ }^{1}$ Fats and Oils Res. Dep., Food Tech. Research Institute,

Agric. Res. Center, Giza, Egypt.

${ }^{2}$ Food Sci. Dep., Faculty of Agric. Saba Basha, Alex. Univ., Alexandria, Egypt.

${ }^{3}$ Oils and Fats Dep., Food Tech. and Nutrition Research

Division, NRC., Egypt.

Received March 05, 2020, Accepted March 30, 2020

\section{INTRODUCTION}

The extraction of oil from rice bran is an important process for the recovery of value-added compounds present in this by-product (Kim et al., 1999). Global interest in rice bran oil (RBO) has increased steadily since it contains a balanced fatty acid composition and is a rich natural source of antioxidants and bioactive compounds, most of them with nutritional, pharmaceutical and cosmetic applications (Chen et al., 2011).

RBO may be added to foods or replaces saturated or hydrogenated fats due to its hypolipidemic activity and its high content of $\gamma$-oryzanol (Wilson et al., 2000). In this sense, most of the human and animal studies reported improvement in the lipid profile, faecal cholesterol and bile acid excretion, regulation of cholesterol synthesis through HMG-CoA reductase and LDL receptor. Additionally, several studies have shown that regular consumption of RBO reduces postprandial and fasting glucose and glycated haemoglobin in streptozotocin-treated rats (Chou et al., 2009), and humans suffering from diabetes mellitus II (Devarajan et al., 2016b) Other activities exerted by RBO in animal models include oxidative stress protection by an increase in antioxidant enzymes as a result of a high ferulic acid from $\gamma$-oryzanol and vitamin $E$ concentration in RBO and anti-inflammatory activities via NF- $\kappa \beta$ inhibition (Rao et al., 2016).

Rice bran oil is highly prone to lipid oxidation during storage and processing operations. Hence, it could be protected against undesirable effects of light, oxygen, temperature . through microencapsulation (Charoen et al., 2011).

Microencapsulation by spray drying is a process in which small particles of a material are trapped in a protective shell (polymer thin films or covers). The material to be encapsulated is known as "core material" or "active material", while the material forming the coating is called "wall material" (Gharsallaoui et al., 2007). 
Microencapsulation is a promising technique to protect unsaturated fatty acids against oxidation, thus increasing their shelf life. Emulsification of lipids in a solution of wall materials followed by spray drying is a process widely used for microencapsulation of oils and flavors. It results in powders with good quality, low water activity, easy handling and storage and also protects the active material against undesirable reactions (Gharsallaoui et al., 2012).

Maltodextrin is a hydrolyzed starch commonly used as wall material in microencapsulation of food ingredients (Gharsallaoui et al., 2007). It offers advantages such as relatively low cost, neutral aroma and taste, low viscosity at high solids concentrations and good protection against oxidation. However, the biggest problem of this wall material is its low emulsifying capacity. Therefore, it is desirable to use maltodextrin in combination with other surface active biopolymers, such as gum Arabic, modified starches (Bule et al., 2010), and proteins (Bae and Lee, 2008) in order to obtain an effective microencapsulation by spray drying.

The emulsion properties such as total solids content, viscosity, stability and droplet size, directly affect the encapsulation efficiency of oils, being of great importance in the microencapsulation by spray drying. A successful microencapsulation must result in a powder with minimum surface oil and maximum retention of the active material (Jafari et al., 2008b).

The stability of emulsions is the most important parameter for the shelf life of the food products (Juttulapa et al., 2017). The droplet size and droplet size distribution are important for stability and viscosity properties of the emulsion. In kinetic approach, those emulsions are stable when the number of droplet, droplet size distribution, and order of the droplet do not change significantly over the period of storage (Sanchez et al., 2001). Moreover, increasing the concentration of the emulsifier can reduce the droplet size of emulsion, which could enhance the emulsion stability. By adding energy to the system the particles will break down into smaller sizes and finally the emulsion becomes more stable which will not be easy to treat.

Furthermore, zeta potential reflects the charged state of the droplet surface in the oil in water $(\mathrm{o} / \mathrm{w})$ emulsion, and it indicates the strength of the repulsion force between droplets. Thus, zeta potential is an important parameter to assess $\mathrm{o} / \mathrm{w}$ emulsions stability. $\mathrm{o} / \mathrm{w}$ emulsions with low zeta potential (negative or positive) are prone to flocculate or coagulate, while o/w emulsions with high zeta potential are electrically stabilized (Li and Xiang, 2019).

Yoghurt is one of the most popular fermented dairy products which are beyand its nutritional value possess a variety of health aspects attributed with probiotic bacteria (Saint-Eve et al., 2006). Past years have seen a global increase in yoghurt consumption due to its benefits, high biological value and bioavailability (ElAbbadi et al., 2014).

Microencapsulation of foods exhibit wide applicability, being an effective and extremely important tool in the preservation of various nutritional components, protecting food and other products from hard processing methods (Gharsallaoui et al., 2012).

The objective of this study is to estimate the physical and chemical properties, fatty acid composition and bioactive compounds of rice bran oil. Evaluate the effect of combining maltodextrin with whey protein concentrate and gum arabic at different concentrations on the microencapsulation of rice bran oil (ERBO) by spray drying. Evaluate the effect of suplementing ERBO on physio-chemical and organoleptic properties of yoghurt samples for adding a value added functional product.

\section{MATERIALS AND METHODS}

\section{Materials:}

10 kilograms of rice (Oryza sativa L.) bran were obtained from a rice mill located at Damanhur, Behira Governorate, Egypt in December 2019. The obtained rice bran was directly transported using an insulated ice box to the fats and oils Dept. Lab., Agricultural Research Center, Giza, Egypt. The bran collected was stored in an airtight container in a freezer $\left(-20^{\circ} \mathrm{C}\right)$ until it was further used for different experiments.

All chemicals used (analytical grades) were purchased from El-Gomhouria Pharmaceutical Company and El-Nasr Pharmaceutical Chemicals Company, Cairo, Egypt. Folin-Ciocateu reagent was obtained from Gerbsaure Chemical Co. Ltd. Germany.

Whey protein concentrate (WPC) contain 80\% proteins as supplier data, gum arabic (GA) and maltodextrin (MD) from Alfasol Co., Turkey.

Milk cow powder (USA) containing $24.5 \%$ protein, $38.3 \%$ lactose, $28.8 \%$ fat, $5.6 \%$ ash and $2.8 \%$ moisture (data are presented by supplier) was used.

Starter strains of $S$. salivarius subsp. Thermophiles, B. bifidum and L.delburkii subsp. Bulgaricus were obtained from stock cultures from the Dairy Microbiology Lab., National Research Center, Dokki, Cairo, Egypt and propagated in sterilized reconstituted milk cow $(10 \% \mathrm{w} / \mathrm{v})$ before use.

\section{Methods:}

\section{Rice bran oil extraction:}

At National Research Center, Dokki, Cairo, Egypt. Crude oil was extracted from the rice bran by using 
hydraulic pressing at room temperature and 250 bar for 2 h. according to Ustun et al. (1990).

\section{Physical and chemical Properties of oil:}

- The refractive index of extracted oil was measured according to AOAC (2012) using Abbe refractometer at $25^{\circ} \mathrm{C}$.

- The colour measurement: The method described by Lee et al. (2004) was applied for measuring colour. The absorbance of $5 \%(\mathrm{w} / \mathrm{v})$ solutions of oil in chloroform was measured at $420 \mathrm{~nm}$. using "Spectronic 20" Spectrophotometer (Bauch \& Lamb).

- Acidity, peroxide value and unsaponifiable matters were determined according to the methods of AOAC (2012).

- UV absorbance at 230 and $270 \mathrm{~nm}$.: Diene and Triene (K230 and K $270 \mathrm{~nm}$.) of oil were determined according to the EEC 25681 (1991) of the extracted oil.

- Oxidative stability: The oxidative stability index (OSI) of oil was measured according to the method described by Mendez et al. (1997).

- Fatty acid composition: The fatty acid methyl esters of oils were prepared using trans-esterification with cold methanolic solution of potassium hydroxide. The fatty acid methyl esters were identified by GCMS according to the method of IOOC (2001).

\section{Bioactive compounds of rice bran oil:}

- The total polyphenols (ppm) was determined according to the method of Gutfinger (1981).

- $\alpha$ - tocopherols ( $\mathrm{ppm})$ were determined according to the method described by Wong et al. (1988).

- $\gamma$ - oryzanol (\%) was determined according to the method of Gopala et al. (2006).

- Chlorophyll and carotenoid contents (ppm) were estimated according to Mosquora et al. (1991) method.

\section{Microencapsulation process:}

Preparation of coating material solution: Hydrated solutions of maltodextrin (MD) at concentration (10\% by weight) were prepared by mixing MD with deionized water overnight using magnetic stirrer (Heidolph MR $3001 \mathrm{~K}$, Heidolph Instruments $\mathrm{GmbH} \& \mathrm{Co}$, Schwabach, Germany). Whey protein concentrate (WPC) solution was prepared by swelling WPC in deionized water and heating up to $40^{\circ} \mathrm{C}$ until the appearance of a homogenous solution. Hydrated solution of gum arabic (GA) at concentration $(10 \%$ by weight) were prepared fresh before use by mixing GA with distilled water using magnetic stirrer (Heidolph MR $3001 \mathrm{~K}$, Heidolph Instruments $\mathrm{GmbH}$ \& Co, Schwabach, Germany) (Gharsallaoui et al., 2012).
Emulsion preparation: In order to get a stable emulsion with ultrasound, coarse emulsion preparation is a crucial step. Therefore, after preparation of coating material solutions separately, a pre-emulsion must be formed by mixing equal amounts (by weight) of MD , WPC and GA solutions at the required concentrations to obtain total solids content of $10 \%(\mathrm{w} / \mathrm{w})$ and MD:WPC: GA ratios of 3:2:0, 3:1:1 and 3:0:2. Then the oil was added to obtain the desired core to coatings at ratios of 1:2, 1:4 at 5,000 rpm and for $5 \mathrm{~min}$ using high-speed blender (IKA T25 digital Ultra-Turrax, Selangor, Malaysia). Mixing of $100 \mathrm{~g}$ solution was performed in $250 \mathrm{ml}$ beaker (Gharsallaoui et al., 2012).

Ultrasonication: Ultrasonic homogenizer (Sonic Ruptor 400, OMNI International the Homogenizer Company, GA, USA) equipped with titanium probe with diameter $25.4 \mathrm{~mm}$. was used for emulsification. Ultrasonic homogenization of $100 \mathrm{~g}$ solution was performed in $250 \mathrm{ml}$ beaker using $80 \%$ power for 10 min at $22^{\circ} \mathrm{C}$ with pulsation $20 \mathrm{~s}$ on and $5 \mathrm{~s}$ off.

Spray drying: Immediately after emulsification with ultrasound, samples were dried in a laboratory scale spray-drier equipped with a $0.5-\mathrm{mm}$. nozzle atomizer (Mini spray-dryer B- 290; BUCHI, Switzerland). Emulsions were pumped to the spray-drier at a feed rate of $1 \mathrm{~L} / \mathrm{h}$ at room temperature and dried at an inlet temperature of $180{ }^{\circ} \mathrm{C}$ and an outlet temperature of 90 ${ }^{\circ} \mathrm{C}$. (Gharsallaoui et al., 2012).

\section{Analysis of encapsulated powder:}

Encapsulation Efficiency: Encapsulation efficiency (EE) analysis was adapted from Millqvist-Fureby (2003). EE was calculated by the following equation:

$$
E E=\left(\frac{T O-S O}{T O}\right) \times 100
$$

Where $T O$ is the total oil content and $S O$ is the surface oil content.

Surface morphology of capsules: The morphology of microspheres was observed under a scanning electron microscope (SEM; carlzeiss EV018) at an acceleration voltage of $15 \mathrm{kV}$ and the micrographs were recorded on ORWO $35 \mathrm{~mm}$ panchromatic film (Tomar and Prasad, 1987).

\section{Emulsion characteristics:}

Emulsion stability: Immediately after the emulsion preparation, $25 \mathrm{~mL}$ aliquots of each sample were transferred to graduated cylinders, $25 \mathrm{~mL}$, sealed, stored at room temperature for one day, and the volume of the aqueous phase measured after $24 \mathrm{~h}$. The stability was measured by $\%$ of separation, by the following equation: 


$$
\% \text { Separation }=\left(\frac{H_{1}}{H_{0}}\right) \times 100
$$

Where: $H_{0}$ represents the emulsion initial height and $H_{l}$ is the upper phase height.

Particle size distribution: The samples of encapsulated preparations were suspended in distilled water (1 $\mathrm{mg} / \mathrm{mL}$ ), The particle size distribution of the emulsion droplets was determined using a light scattering instrument (Surface Zeta Potential and Particle Size Analyzer, ELS-8000, Company Otsuka Electronics, Japan) (Surh et al., 2007).

\section{Preparation of yoghurt:}

Milk cow powder (14\%) reconstituted in distilled water, and then divided into 2 parts. The first part was standard to $4 \%$ fat and used as a control. The second part was partial replaced and homogenized with 2, 4, $6 \%$ of encapsulated rice bran oil (ERBO), and $2 \%$ RBO. The control milk and treated samples were heated at $85^{\circ} \mathrm{C}$ for $30 \mathrm{~min}$ and cooled directly to $45^{\circ} \mathrm{C}$ then inoculated with starter bacteria $S$. salivarius subsp. Thermophiles, B. bifidum and L.delburkii subsp. Bulgaricus $(1: 1: 1)$ at $3 \%(\mathrm{v} / \mathrm{v})$. The previous treatments were incubated at $42^{\circ} \mathrm{C}$ until the curd formed then stored in refrigerator at $5 \pm 2{ }^{\circ} \mathrm{C}$ for 14 days. All samples were analyzed at intervals of zero, 7 and 14 days of storage.

pH and titratable acidity (TA): $\mathrm{pH}$ was measured by pH meter (Carry Series UV-Vis Spectrophotometer, Malaysia) equipped with combined electrode. TA of yoghurt was measured according to the AOAC (2000), and the results were expressed as lactic acid\%.

Water-holding capacity (WHC): Water holding capacity was determined according to Arslan and Ozel (2012). The WHC \% calculated by using the following equation:

$$
\mathrm{WHC}=\left(\frac{\mathrm{NY}-\mathrm{WE}}{\mathrm{NY}}\right) \times 100
$$

Where: NY is weight of native yoghurt.

WE is weight of whey expelled.

Sensory Evaluation: Ten panelists (from the staff members of the Food Technology Research Institute (Alexandria Lab.), Agricultural Research Center, Egypt) participated in a sensory evaluation of yoghurt and tested the samples at intervals of storage periods (zero time, 7 and 14 days). The samples were rated at a nine point scale for colour/appearance, flavour/taste, body/texture and overall acceptability as prescribed by Herald et al. (2008).

Statistical Analysis: The GLM procedure with software was applied for analyzing the obtained data (SAS., 1994). Duncan's multiple range test was conducted to compare between the sample means. A probability to $\mathrm{p} \leq 0.05$ was used to recognize the statistical significance.

\section{RESULTS AND DISCUSSION}

\section{Physical and chemical characteristics of rice bran oil (RBO):}

The physical and chemical properties of extracted RBO by hydraulic press are given in Table (1). The results obtained indicated that, RBO is of a good quality as evidenced by its initial refractive index (1.4721 at $\left.25^{\circ} \mathrm{C}\right)$, colour at $420 \mathrm{~nm}$. (0.330), peroxide value $(2.25$ meq $\mathrm{O}_{2} / \mathrm{kg}$ oil) and acidity $(5.35 \%)$. Furthermore, the diene and triene (K230 and K270 nm.) of RBO were found to be 0.330 and $0.170 \mathrm{~nm}$., respectively, which are below the average range for vegetable oils. Also, the unsaponifiable matters and stability of this oil were 6.89 $\%$ and $31.1 \mathrm{~h}$. at $100{ }^{\circ} \mathrm{C}$, respectively. Since RBO is highly prone to lipid oxidation during storage and processing hence, it may to be protected against undesirable effects of light, oxygen, temperature through microencapsulation (Charoen et al., 2011).

In regard to the results in Table (1), RBO contained considerable amounts of saturated fatty acids (22.99\%) represented in palmitic and stearic acids being 20.53 and $1.59 \%$, respectively, also it contained high amounts of unsaturated fatty acids (77.01\%) represented in 39.76 $\%$ oleic acid (monounsaturated fatty acid $(\omega-9)$ ) and $35.93 \%$ linoleic acid (polyunsaturated fatty acid $(\omega-6)$ ) which contribute to the health properties of RBO, also linoleic acid is one of the most important polyunsaturated fatty acids in the human food due to its prevention of cardiovascular heart disease (Chen et al., 2011). Results also clarified that, RBO is a good source of bioactive components (total polyphenols, $\alpha$ tocopherol, $\gamma$ - oryzanol, chlorophyll and carotenoids contents) which were $15.91 \mathrm{ppm}, 244.59 \mathrm{ppm}, 1.75 \%$, $10.22 \mathrm{ppm}$ and $2.57 \mathrm{ppm}$, respectively.

The previous results also emphasize the fact that, RBO is a nutritional supplement for natural source of essential fatty acids, unsaponifiable matters, $\alpha$ tocopherol, $\gamma$ - oryzanol, chlorophyll and carotenoids contents. 
Table 1. Physico-chemical characteristics, fatty acid composition and bioactive compounds of rice bran oil

\begin{tabular}{|c|c|}
\hline Physical and chemical properties & Value \\
\hline $\mathrm{RI}$ at $25^{\circ} \mathrm{C}$ & $1.4721 \pm 0.04$ \\
\hline Colour at $420 \mathrm{~nm}$. & $0.330 \pm 0.02$ \\
\hline FFA ( $\%$ as oleic acid) & $5.35 \pm 0.11$ \\
\hline $\mathrm{PV}\left(\right.$ meq $\mathrm{O}_{2} / \mathrm{kg}$ oil) & $2.25 \pm 0.20$ \\
\hline $\mathrm{K} 230 \mathrm{~nm}$. & $0.330 \pm 0.06$ \\
\hline $\mathrm{K} 270 \mathrm{~nm}$. & $0.170 \pm 0.06$ \\
\hline Unsaponifiable matters (\%) & $6.89 \pm 0.39$ \\
\hline Oxidative stability index (h. at $100^{\circ} \mathrm{C}$ ) & $31.10 \pm 1.50$ \\
\hline \multicolumn{2}{|c|}{ Fatty acids composition ( $\%$ of total fatty acids): } \\
\hline Myristic acid (C14:0) & 0.36 \\
\hline Palmitic acid (C16:0) & 20.53 \\
\hline Stearic acid $(\mathrm{C} 18: 0)$ & 1.59 \\
\hline Arachadic acid (C20:0) & 0.51 \\
\hline Oleic acid $(\mathrm{C} 18: 1)(\omega-9)$ & 39.76 \\
\hline Linoleic acid $(\mathrm{C} 18: 2)(\omega-6)$ & 35.93 \\
\hline Linolenic acid $(\mathrm{C} 18: 3)(\omega-3)$ & 1.32 \\
\hline Total saturated fatty acid (TSFA) & 22.99 \\
\hline TUSFA & 77.01 \\
\hline \multicolumn{2}{|l|}{ Bioactive compounds } \\
\hline Total polyphenols (ppm as caffeic acid) & $15.91 \pm 2.50$ \\
\hline$\alpha$ - tocopherol (ppm) & $244.54 \pm 0.64$ \\
\hline$\gamma$ - oryzanol $(\%)$ & $1.75 \pm 0.01$ \\
\hline Chlorophyll (ppm) & $10.22 \pm 0.04$ \\
\hline Carotenoids (ppm) & $2.57 \pm 0.01$ \\
\hline
\end{tabular}

Values are expressed as means of triplicate determination \pm SD.

\section{Encapsulation efficiency of encapsulated powder:}

Encapsulation efficiency (EE) of the samples produced from emulsions prepared with different coating materials, maltodextrin (MD), whey protein concentrate (WPC) and gum arabic (GA), mixed at different ratios which were $3: 2,2: 1: 1$ and $3: 2$ for MD: WPC, MD: WPC: GA and MD: GA, respectively and core to coating materials at $1: 2$ and $1: 4$ ratios are presented in Table (2) and Fig (1).

Table 2. Surface oil content $(\mathrm{g} / \mathrm{g})$ of capsules prepared with different wall materials and core to wall materials

\begin{tabular}{ccc}
\hline Formulations of wall materials & Core $:$ wall materials & Surface oil content $(\mathrm{g} / \mathrm{g})$ \\
\hline MD $:$ WPC $: \mathrm{GA}$ & & \\
\hline $3: 2: 0$ & $1: 2$ & $0.37 \pm 0.01^{\mathrm{a}}$ \\
$3: 2: 0$ & $1: 4$ & $0.32 \pm 0.02^{\mathrm{ab}}$ \\
$3: 1: 1$ & $1: 4$ & $0.30 \pm 0.06^{\mathrm{ab}}$ \\
$3: 1: 1$ & $1: 2$ & $0.22 \pm 0.01^{\mathrm{c}}$ \\
$3: 0: 2$ & $1: 4$ & $0.27 \pm 0.02^{\mathrm{bc}}$ \\
$3: 0: 2$ & & $0.22 \pm 0.03^{\mathrm{c}}$ \\
\hline
\end{tabular}

Values are expressed as means of triplicate determination \pm SD.

Means with the same letter are not significantly different at $\mathrm{p} \leq 0.05$. 


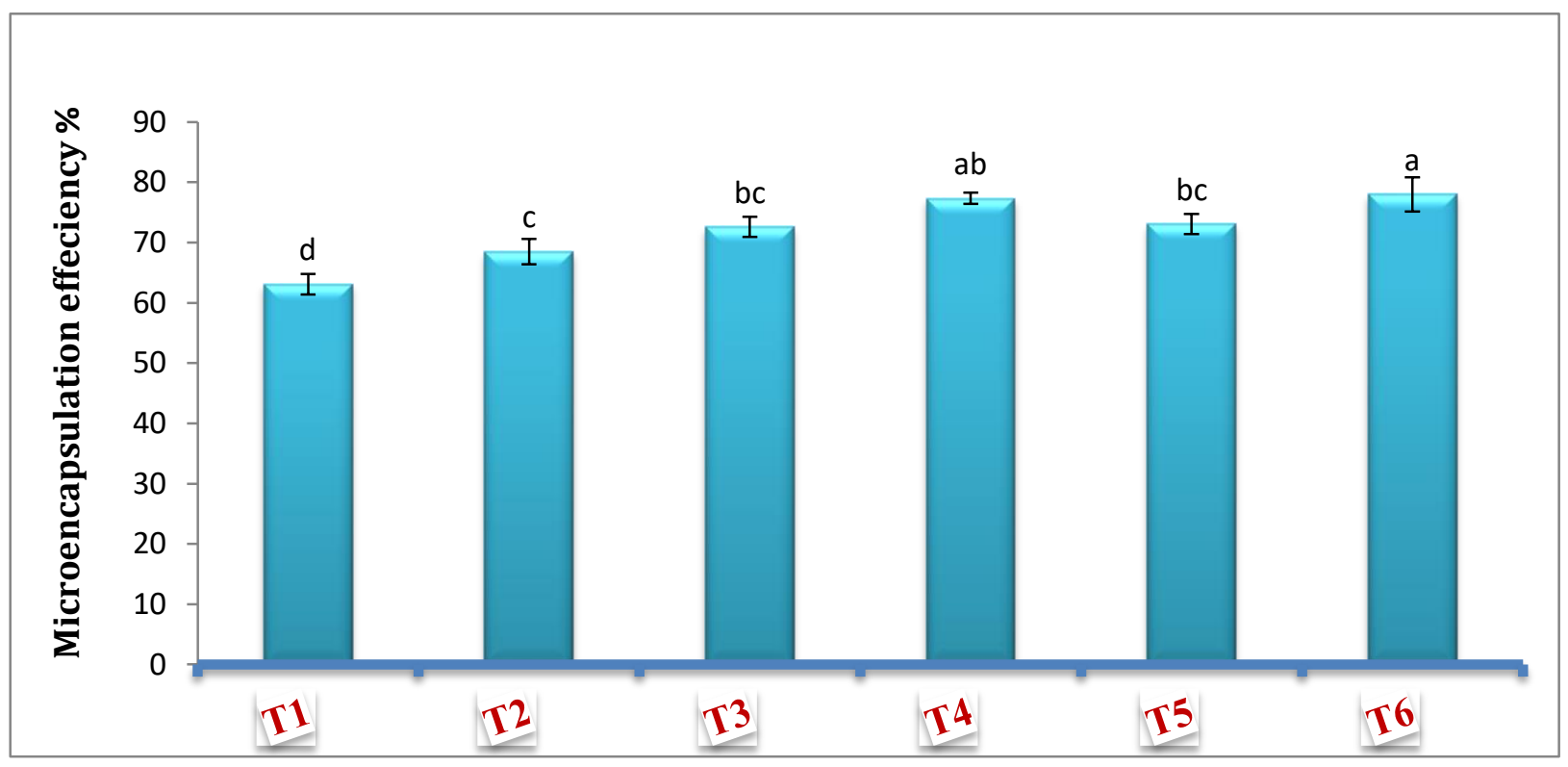

The data represent the average value \pm standard deviation.

Means with the same letter are not significantly different at $\mathrm{p} \leq 0.05$.

\section{Whereas:}

T1: MD: WPC (3:2) and 1:2 core: coating ratio.

T3: MD: WPC: GA (3:1:1) and 1:2 core: coating ratio.

T5: MD: GA (3:2) and 1:2 core: coating ratio.
T2: MD: WPC (3:2) and 1:4 core: coating ratio.

T4: MD: WPC: GA (3:1:1) and 1:4 core: coating ratio.

T6: MD: GA (3:2) and 1:4 core: coating ratio.

\section{Fig. 1. Effeciency of encapsulated rice bran oil}

The results in Fig (1). clarified the fact that, there was significant influence for ratios of core to wall material on the EE, where, EE recorded the highest values $(68.5,77.33$ and $78 \%)$ for previous mixture at ratios $3: 2,3: 1: 1$ and $3: 2$, respectively, which were obtained from core : coating materials $1: 4$ ratio, but these values recorded a slight decrease $(63.09,72.62$ and $73.09 \%$ ), respectively for the same previous mixture ratios which were obtained from core : coating materials 1:2 ratio. Accordingly, encapsulation efficiency was found to be maximum at 3:2 for mixture MD:GA that means the mixture of MD with GA caused a decrease in the surface oil content and an increase in EE. This may be due to the film forming property and stabilizing effect of GA (Alftren et al., 2012). The results were in agreement with Krishnan et al. (2005), which shows that the use of MD / GA as coat material for encapsulation of cardamom oleoresin resulted in better EE.

\section{Surface morphology of capsules:}

Fig. (2) shows the surface morphology of encapsulated RBO powder produced at ratios 1:2 and 1:4 for core: coating materials, combination of MD:
WPC, MD: WPC: GA and MD: GA ratios 3:2, 3:1:1 and $3: 2$, respectively. From all tested surfaces, the surface morphology of encapsulated microcapsules obtained from mixture MD:GA at ratio 3:2 was the best formulation, where most of the particles are smooth spheres with little appendages and no cracks or fissures in the wall system compared with other ratios under investigation.

The smooth surface is related to faster film formation, which also explains the better encapsulation efficiency and lower oil oxidation observed in these powders (Jafari et al., 2008b). It was reported that, faster solidification of fish oil emulsion during spray drying resulted in smooth powder particles with less surface dents and shrinkage. Similar results of powder surface morphology were also reported for spray dried chia essential oil emulsions (Rodea-González et al., 2012).

When different core to coating ratios are compared at the same combination of coating materials it was seen that there was no significant difference between SEM images. 


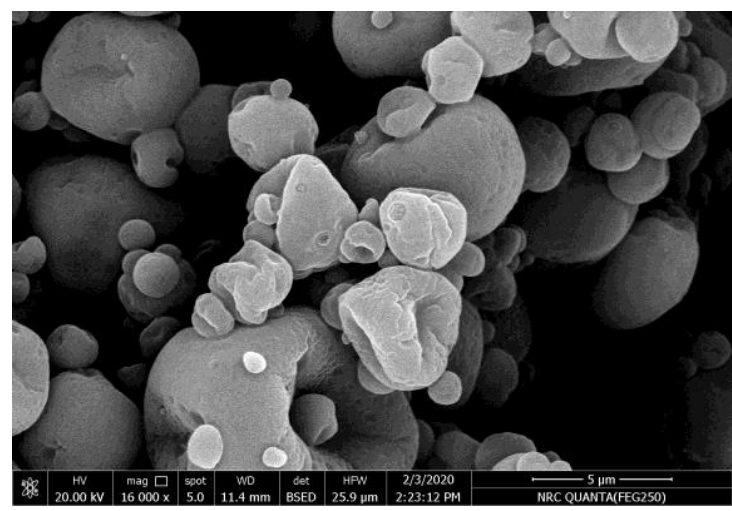

(T1)

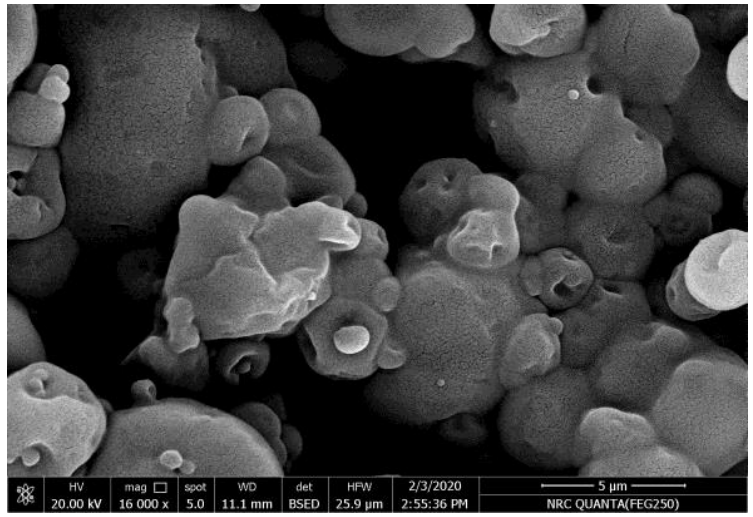

(T3)

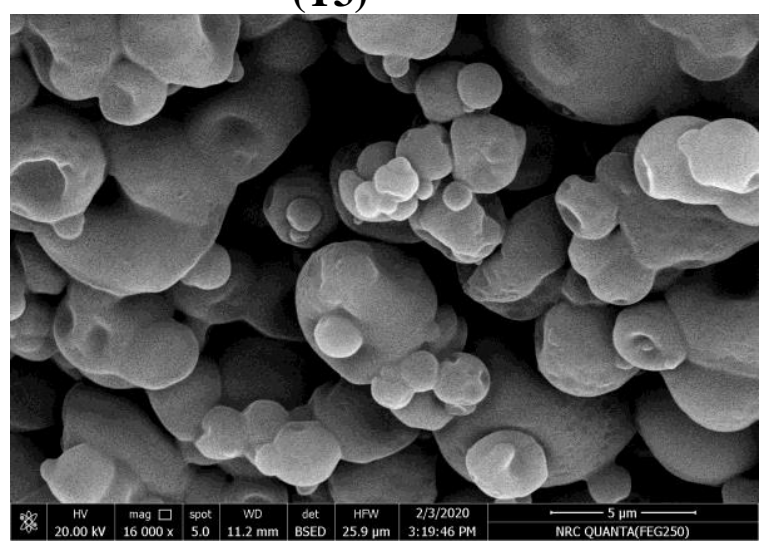

(T5)

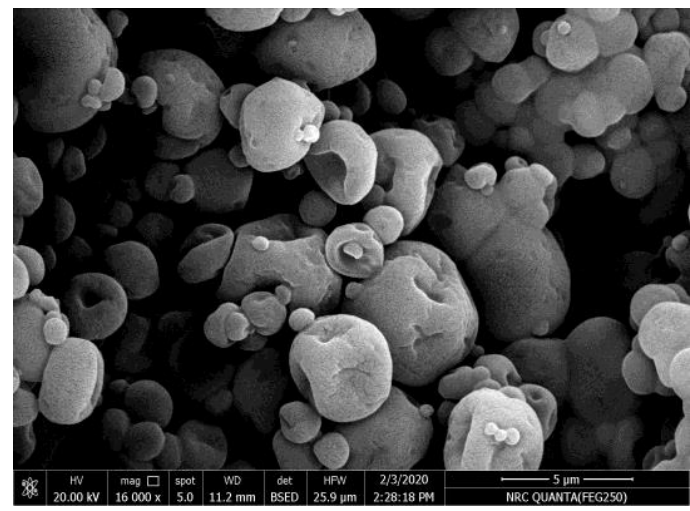

(T2)

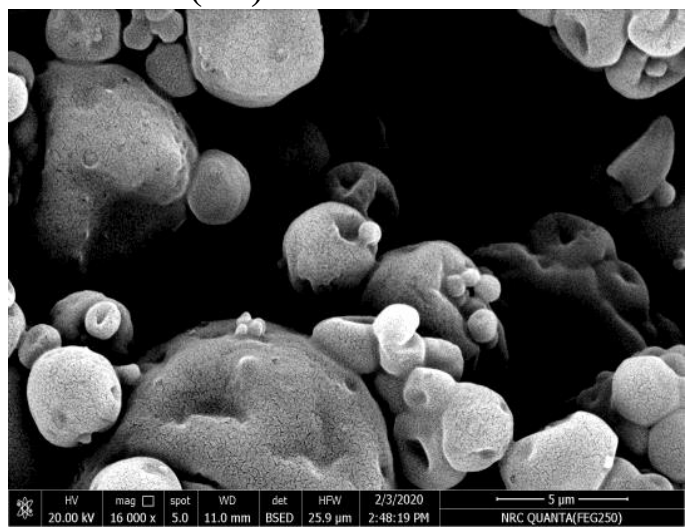

(T4)

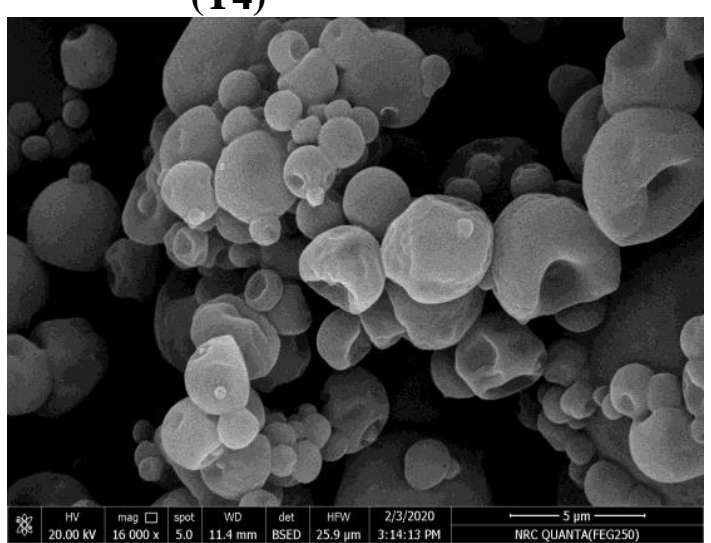

(T6)

Whereas:

T1: MD: WPC (3:2) and 1:2 core: coating ratio.

T2: MD: WPC (3:2) and 1:4 core: coating ratio.

T3: MD: WPC: GA (3:1:1) and 1:2 core: coating ratio.

T4: MD: WPC: GA $(3: 1: 1)$ and $1: 4$ core: coating ratio.

T5: MD: GA (3:2) and 1:2 core: coating ratio.

T6: MD: GA (3:2) and 1:4 core: coating ratio.

Fig.2. External micro structures of powders produced from different wall material combinations and core: wall materials ratio 


\section{Characterization of emulsions:}

Table (3) represents the stability, particle size distribution and zeta potential of core to coating materials at 1:4 with coating materials at different ratios (3:2, 2:1:1 and 3:2) for MD: WPC, MD: WPC: GA and MD: GA, respectively. The results showed that, the stability of emulsion prepared with combination of MD: WPC, MD: WPC: GA and MD: GA for the same previous ratios were $89,94.7$ and $100 \%$ respectively. It is clear that, the mixture of MD:GA at ratio $3: 2$ exhibited the best stability meaning that the oil separation layer was zero, but the stability of the MD: WPC formulation (3:2) of prepared emulsion was reduced to $89 \%$, which means that, the oil separation layer increased to $11 \%$, therefore, the oil separation increased by the adding of WPC to formulation of wall materials. These results may have been caused by the unfolding of the protein molecules at the droplets surface, which would enhance protein-protein interaction leading to flocculation during emulsification and consequently reducing the emulsion stability (Dickinson and Matsumura, 1991).

From the results presented in Table (3) there was significant difference in particle size (diameter droplets) of prepared emulsion as a result of using different wall materials. The emulsion prepared from MD: WPC at ratio 3:2 had the biggest diameter droplets $(882.5 \mathrm{~nm}$.) when compared to the other formulation materials. Meanwhile, the prepared emulsion with MD: GA at ratio 3:2 recorded the smallest diameter droplets (249.8 $\mathrm{nm}$.). This may be due to the highest viscosity presented by the MD: GA emulsion, which implies in a greater resistance to droplets movement, avoiding coalescence and resulting in smaller diameters (Carneiro et al., 2013).

From the illustrated data in Table (3), values of zeta potential of prepared emulsion with MD:WPC, MD:WPC:GA and MD: GA mixtures at the same previous ratios ranged from -21.5 to $-31.49 \mathrm{mV}$, values of approximately $-30 \mathrm{mV}$ may be suitable values that guarantees repulsive forces that promote emulsion stability (Oh et al., 2011).

\section{Changes in the physical and chemical properties of yoghurt:}

Rice bran oil and microcapsules prepared with MD:GA at ratio 3:2 with RBO as a core to coat materials at ratio 1:2 were used to supplement yoghurt and compared to control samples to study the physical and chemical properties of the produced yoghurt samples during storage.

The results in Table (4), reveal, the changes in the physical and chemical characteristics ( $\mathrm{pH}$ value, titratable acidity and water holding capacity) of control and supplemented yoghurt samples with rice bran oil (2\% RBO) and encapsulated rice bran oil (ERBO) (2, 4 and $6 \%$ ) during storage at $5 \pm 2{ }^{\circ} \mathrm{C}$. (Zero time, 7 days and 14 days). The results in Table (4) elucidated that, the $\mathrm{pH}$ values of produced yogurt from ERBO increased as the storage period elapsed.

Also, the $\mathrm{pH}$ values of yoghurt with $\mathrm{RBO}$ were decreased at the end of storage period compared to control sample. On the contrary, the results in Table (4) indicated that, the values of titratable acidity (TA) of yogurt samples significantly increased by increasing ERBO percentage and storage period compared to control samples, also adding of RBO at $2 \%$ to yoghurt increased TA value along the storage period, when compared to control sample. Decreasing $\mathrm{pH}$ and increasing TA in yogurt samples during storage is due to perpetuity of metabolic activity of yoghurt starters, which by more lactose fermentation, continue to lactic acid production, known as over-acidification or postacidification (Serra et al., 2009). Higher TA of enriched yogurt compared to control probably refers to acidity of added-RBO and ERBO. However, TA of enriched yoghurt was within the range of set-style yoghurt.

Table 3. Characterization of prepared emulsions with core and wall materials

\begin{tabular}{|c|c|c|c|c|}
\hline $\begin{array}{l}\text { formulations } \\
\text { MD : WPC :GA }\end{array}$ & $\begin{array}{l}\text { Core : Wall } \\
\text { material }\end{array}$ & Separation \% & $\begin{array}{l}\text { Particle size distribution } \\
\qquad(\mathrm{nm} .)\end{array}$ & Zeta potential $(\mathrm{mV})$ \\
\hline $3: 2: 0$ & $1: 4$ & $11.00 \pm 1.41$ & $882.5 \pm 0.942$ & -21.5 \\
\hline $3: 1: 1$ & $1: 4$ & $5.30 \pm 0.00$ & $350.5 \pm 0.611$ & -27.40 \\
\hline $3: 0: 2$ & $1: 4$ & 0.00 & $249.8 \pm 0.548$ & -31.49 \\
\hline
\end{tabular}

Values are expressed as means of triplicate determination \pm SD. 
The data in Table (4) revealed changes in the WHC values of yoghurt samples as a result of prolonged storage period and the addition of RBO (2\%) and ERBO $(2,4$ and $6 \%)$. The values of WHC of yoghurt samples increased significantly by increasing of concentration of ERBO and storage period. Also adding 2\% RBO to yoghurt samples caused insignificantly increase in this value compared to control sample. These results are in agreement with those reported by Tamjidi et al., (2012), which reported that the WHC of enriched yoghurt with encapsulated fish oil at all times of analysis was higher than control. WHC of enriched yoghurt increased on the 14 th day as compared to the 1 st day of storage at $4^{\circ} \mathrm{C}$, but disagreed with control samples, which decreased at 14th day of storage.

Generally, the encapsulated RBO powder increased WHC of enriched yoghurt.This may be due to the increase of the amount of bound water and decrease in whey separation. It was reported that low WHC and whey separation are related to an unstable gel network and extreme rearrangement of a weak gel network (Lucey 2001).

\section{Organoleptic properties of yoghurt:}

Table (5) shows the changes in the organoleptic properties (colour/ appearance, flavour/taste, body/texture, and the overall acceptability) of control and supplemented yoghurt samples with different concentrations of encapsulated rice bran oil $(2,4$ and $6 \%)$ and with rice bran oil (2\%) during storage periods (zero time, 7 and 14 days). Concerning color scores, no significant differences were observed starting from the $7^{\text {th }}$ day of storage. However panelists scored significant lower color acceptance as the level of ERBO increased but still better than RBO $2 \%$.

No significant differences were observed during storage period concerning flavour of yoghurt however, there were significant decrease in flavour scores as the level of supplementation increased. This decrease in flavour scores are still within the acceptance level and significantly different than RBO $2 \%$. As for texture, it was obvious that, panelists scores significantly decreased as the storage time elapsed. Moreover, panelists gave significant decreased scores to texture as the level of supplementation increased where RBO $2 \%$ recorded the least score.

As a matter of fact, panelists scores showed high acceptance to ERBO yoghurt up to $6 \%$ unlike RBO $2 \%$.

Table 4. Changes in physical and chemical characteristics of yoghurt samples during storage periods

\begin{tabular}{|c|c|c|c|c|c|c|c|}
\hline \multirow{3}{*}{ 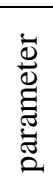 } & \multirow{3}{*}{$\begin{array}{c}\text { Storage } \\
\text { periods } \\
\text { (day) }\end{array}$} & \multicolumn{5}{|c|}{ Yoghurt samples supplemented with: } & \multirow{3}{*}{ Mean } \\
\hline & & \multirow[t]{2}{*}{ Control } & \multicolumn{3}{|c|}{ ERBO } & $\mathrm{RBO}$ & \\
\hline & & & $2 \%$ & $4 \%$ & $6 \%$ & $2 \%$ & \\
\hline \multirow{4}{*}{$\frac{T}{2}$} & Zero time & $4.68 \pm 0.03^{\mathrm{a}}$ & $4.65 \pm 0.01^{\mathrm{b}}$ & $4.62 \pm 0.01^{\mathrm{c}}$ & $4.59 \pm 0.01^{\mathrm{e}}$ & $4.54 \pm 0.02^{\mathrm{f}}$ & $4.61 \pm 0.05 \mathrm{~A}$ \\
\hline & 7 & $4.62 \pm 0.02^{\mathrm{c}}$ & $4.62 \pm 0.01^{\mathrm{c}}$ & $4.6 \pm 0.01^{\mathrm{de}}$ & $4.58 \pm 0.01^{\mathrm{e}}$ & $4.52 \pm 0.02^{\mathrm{g}}$ & $4.58 \pm 0.04 \mathrm{~B}$ \\
\hline & 14 & $4.6 \pm 0.01^{\mathrm{de}}$ & $4.59 \pm 0.00^{\mathrm{e}}$ & $4.58 \pm 0.01^{\mathrm{e}}$ & $4.55 \pm 0.01^{\mathrm{f}}$ & $4.47 \pm 0.02^{\mathrm{h}}$ & $4.55 \pm 0.05 \mathrm{C}$ \\
\hline & Mean & $4.63 \pm 0.04 \mathrm{~A}$ & $4.62 \pm 0.02 \mathrm{~A}$ & $4.59 \pm 0.02 \mathrm{~B}$ & $4.57 \pm 0.04 \mathrm{C}$ & $4.51 \pm 0.04 \mathrm{D}$ & \\
\hline \multirow{4}{*}{ 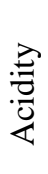 } & Zero time & $0.75 \pm 0.00^{\mathrm{f}}$ & $0.77 \pm 0.02^{\mathrm{f}}$ & $0.88 \pm 0.02^{\mathrm{de}}$ & $1.02 \pm 0.01^{\mathrm{c}}$ & $1.02 \pm 0.01^{\mathrm{c}}$ & $0.89 \pm 0.12 \mathrm{C}$ \\
\hline & 7 & $0.76 \pm 0.01^{\mathrm{f}}$ & $0.87 \pm 0.03^{\mathrm{de}}$ & $0.92 \pm 0.02^{\mathrm{d}}$ & $1.03 \pm 0.01^{\mathrm{c}}$ & $1.09 \pm 0.01^{\mathrm{b}}$ & $0.93 \pm 0.12 B$ \\
\hline & 14 & $0.84 \pm 0.08^{\mathrm{e}}$ & $0.91 \pm 0.09^{\mathrm{d}}$ & $0.99 \pm 0.02^{\mathrm{c}}$ & $1.04 \pm 0.01^{\mathrm{c}}$ & $1.17 \pm 0.04^{\mathrm{a}}$ & $0.99 \pm 0.13 \mathrm{~A}$ \\
\hline & Mean & $0.78 \pm 0.06 \mathrm{E}$ & $0.85 \pm 0.08 \mathrm{D}$ & $0.93 \pm 0.05 \mathrm{C}$ & $1.02 \pm 0.01 \mathrm{~B}$ & $1.09 \pm 0.07 \mathrm{~A}$ & \\
\hline \multirow{4}{*}{$\frac{U}{3}$} & Zero time & $60.5 \pm 1.73^{\mathrm{h}}$ & $61.0 \pm 1.73^{\mathrm{gh}}$ & $63.5 \pm 4.04^{\mathrm{fg}}$ & $65.5 \pm 0.58^{\mathrm{ef}}$ & $63.5 \pm 0.58^{\mathrm{fg}}$ & $62.8 \pm 2.6 \mathrm{C}$ \\
\hline & 7 & $64.0 \pm 2.31^{\mathrm{fg}}$ & $64.0 \pm 3.5^{\mathrm{fg}}$ & $65.0 \pm 1.15^{\mathrm{f}}$ & $66.0 \pm 0.00^{\mathrm{ef}}$ & $64.0 \pm 2.31^{\mathrm{fg}}$ & $64.6 \pm 2.11 \mathrm{~B}$ \\
\hline & 14 & $68.0 \pm 2.31^{\mathrm{de}}$ & $72.0 \pm 0.00^{\mathrm{bc}}$ & $72.5 \pm 0.58^{b}$ & $77.5 \pm 1.73^{\mathrm{a}}$ & $69.5 \pm 1.73^{\mathrm{cd}}$ & $71.9 \pm 3.6 \mathrm{~A}$ \\
\hline & Mean & $64.2 \pm 3.7 \mathrm{C}$ & $65.7 \pm 5.17 \mathrm{BC}$ & $67.0 \pm 4.67 \mathrm{~B}$ & $69.7 \pm 5.87 \mathrm{~A}$ & $65.7 \pm 3.2 \mathrm{BC}$ & \\
\hline
\end{tabular}

The data represent the average value \pm standard deviation. The different small letters in the columns and rows represent statistically significant differences $(\mathrm{p} \leq 0.05)$.

Means with the same capital letter are not significantly different at $\mathrm{p} \leq 0.05$. 
Table 5. Organoleptic properties of yoghurt samples during storage periods at $5 \pm 2^{\circ} \mathrm{C}$

\begin{tabular}{|c|c|c|c|c|c|c|c|}
\hline \multirow{3}{*}{ 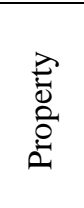 } & \multirow{3}{*}{$\begin{array}{r}\text { Storage } \\
\text { period } \\
\text { (day) }\end{array}$} & \multicolumn{6}{|c|}{ Yoghurt samples supplemented with: } \\
\hline & & Control & & ERBO & & $\mathrm{RBO}$ & Mean \\
\hline & & & $2 \%$ & $4 \%$ & $6 \%$ & $2 \%$ & \\
\hline \multirow{4}{*}{ 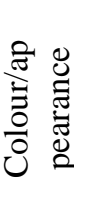 } & Zero time & $9.00 \pm 0.00^{\mathrm{a}}$ & $8.83 \pm 0.39^{\mathrm{ab}}$ & $8.33 \pm 0.78^{\mathrm{bcd}}$ & $8.17 \pm 0.94^{\text {cde }}$ & $7.67 \pm 0.58^{\mathrm{ef}}$ & $8.40 \pm 0.77 \mathrm{~A}$ \\
\hline & 7 & $8.83 \pm 0.25^{\mathrm{ab}}$ & $8.67 \pm 0.49^{\mathrm{abc}}$ & $8.25 \pm 0.58^{\mathrm{cd}}$ & $8.00 \pm 0.85^{\mathrm{de}}$ & $7.42 \pm 0.47^{\mathrm{fg}}$ & $8.23 \pm 0.74 \mathrm{AB}$ \\
\hline & 14 & $8.67 \pm 0.49^{\mathrm{abc}}$ & $8.58 \pm 0.47^{\mathrm{abc}}$ & $8.25 \pm 0.84^{\mathrm{cd}}$ & $7.83 \pm 0.72^{\mathrm{def}}$ & $7.08 \pm 0.36^{\mathrm{g}}$ & $8.08 \pm 0.82 \mathrm{~B}$ \\
\hline & Mean & $8.83 \pm 0.34 \mathrm{~A}$ & $8.69 \pm 0.45 \mathrm{~A}$ & $8.27 \pm 0.72 \mathrm{~B}$ & $8.00 \pm 0.83 \mathrm{~B}$ & $7.39 \pm 0.52 \mathrm{C}$ & \\
\hline \multirow{4}{*}{$\begin{array}{l}\bar{\Xi} \\
\overline{0} \\
\frac{\Xi}{I} \\
I\end{array}$} & Zero time & $8.83 \pm 0.39^{\mathrm{a}}$ & $8.08 \pm 0.58^{\mathrm{bcd}}$ & $8.33 \pm 0.49^{\mathrm{abc}}$ & $8.33 \pm 0.78^{\mathrm{abc}}$ & $7.58 \pm 0.47^{\mathrm{ef}}$ & $8.23 \pm 0.71 \mathrm{~A}$ \\
\hline & 7 & $8.58 \pm 0.36^{\mathrm{ab}}$ & $8.00 \pm 0.60^{\text {cde }}$ & $8.25 \pm 0.39^{\mathrm{bc}}$ & $8.17 \pm 0.76^{\text {bcd }}$ & $7.42 \pm 0.56^{\mathrm{f}}$ & $8.08 \pm 0.68 \mathrm{~A}$ \\
\hline & 14 & $8.50 \pm 0.52^{\mathrm{abc}}$ & $8.00 \pm 0.67^{\text {cde }}$ & $8.17 \pm 0.49^{\mathrm{bcd}}$ & $8.08 \pm 0.87^{\mathrm{bcd}}$ & $7.08 \pm 0.82^{\mathrm{fg}}$ & $7.97 \pm 0.83 \mathrm{~A}$ \\
\hline & Mean & $8.64 \pm 0.44 \mathrm{~A}$ & $8.03 \pm 0.59 \mathrm{~B}$ & $8.25 \pm 0.46 \mathrm{~B}$ & $8.19 \pm 0.78 \mathrm{~B}$ & $7.36 \pm 0.65 \mathrm{C}$ & \\
\hline \multirow{4}{*}{ 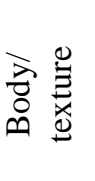 } & Zero time & $8.83 \pm 0.39^{\mathrm{a}}$ & $8.50 \pm 0.52^{\mathrm{abc}}$ & $8.17 \pm 0.39^{\mathrm{cd}}$ & $8.08 \pm 0.47^{\text {cde }}$ & $7.92 \pm 0.56^{\mathrm{def}}$ & $8.30 \pm 0.56 \mathrm{~A}$ \\
\hline & 7 & $8.75 \pm 0.39^{\mathrm{ab}}$ & $8.33 \pm 0.49^{\mathrm{bcd}}$ & $8.08 \pm 0.19^{\text {cde }}$ & $7.92 \pm 0.39^{\mathrm{def}}$ & $7.58 \pm 0.56^{\mathrm{f}}$ & $8.13 \pm 0.59 \mathrm{~B}$ \\
\hline & 14 & $8.67 \pm 0.49^{\mathrm{ab}}$ & $8.33 \pm 0.78^{\mathrm{bcd}}$ & $7.92 \pm 0.47^{\mathrm{def}}$ & $7.92 \pm 0.58^{\mathrm{def}}$ & $7.58 \pm 0.39^{\mathrm{f}}$ & $8.08 \pm 0.87 \mathrm{C}$ \\
\hline & Mean & $8.75 \pm 0.42 \mathrm{~A}$ & $8.39 \pm 0.59 \mathrm{~B}$ & $8.06 \pm 0.37 \mathrm{C}$ & $7.97 \pm 0.51 \mathrm{C}$ & $7.39 \pm 0.73 \mathrm{D}$ & \\
\hline \multirow{4}{*}{ 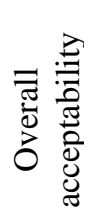 } & Zero time & $9.00 \pm 0.00^{\mathrm{a}}$ & $8.50 \pm 0.52^{\mathrm{bc}}$ & $8.50 \pm 0.79^{b c}$ & $8.25 \pm 0.49^{\text {cde }}$ & $7.50 \pm 0.43^{\mathrm{ef}}$ & $8.35 \pm 0.71 \mathrm{~A}$ \\
\hline & 7 & $8.75 \pm 0.26^{\mathrm{ab}}$ & $8.33 \pm 0.49^{\mathrm{bcd}}$ & $8.33 \pm 0.78^{\mathrm{bcd}}$ & $8.17 \pm 0.19^{\text {cde }}$ & $7.17 \pm 0.49^{\mathrm{fg}}$ & $8.15 \pm 0.72 B$ \\
\hline & 14 & $8.50 \pm 0.52^{\mathrm{bc}}$ & $8.25 \pm 0.72^{\text {cde }}$ & $8.08 \pm 0.36^{\text {cde }}$ & $8.08 \pm 0.25^{\text {cde }}$ & $7.08 \pm 0.47^{\mathrm{g}}$ & $7.99 \pm 0.73 \mathrm{C}$ \\
\hline & Mean & $8.75 \pm 0.39 \mathrm{~A}$ & $8.36 \pm 0.58 \mathrm{~B}$ & $8.31 \pm 0.68 \mathrm{~B}$ & $8.17 \pm 0.36 \mathrm{~B}$ & $7.19 \pm 0.51 \mathrm{C}$ & \\
\hline
\end{tabular}

The data represent the average value \pm standard deviation. The different small letters in the columns and rows represent statistically significant differences $(\mathrm{p} \leq 0.05)$.

Means with the same capital letter are not significantly different at $\mathrm{p} \leq 0.05$.

\section{CONCLUSION AND RECOMMENDATIONS}

Rice bran oil was encapsulated by spray- drying method and prepared with MD:WPC, MD:WPC:GA and MD:GA at ratios 3:2, 3:1:1 and 3:2, respectively, were used with RBO (core) to coating materials at ratios 1:2 and 1:4. Microcapsules produced from MD: GA at ratio $3: 2$ and core to wall material 1:4 gave the highest value of encapsulation efficiency and smallest value of particle size for capsules powder. The application of microparticles in yoghurt, the ratio at MD: GA 3:2 and the ratio between $\mathrm{RBO}$ and wall materials were 1:2 has the best economic potential to be successfully applied. Scores of organoleptic properties of yoghurt with ERBO samples were almost nearly from scores of the control sample during storage periods. Therefore, microcapsules prepared with MD: GA at ratio 3:2 with core to wall materials $1: 2$ can be utilized as a functional food.

\section{REFERENCES}

Alftren, J., J. Penarrieta, B. Bergenstahl and L. Nilsson. 2012. Comparison of molecular and emulsifying properties of gum arabic and mesquite gum using asymmetrical flow field-flow fractionation.Food Hydrocolloids. 26(1):54-62.
AOAC. 2000. Official methods of analysis. Arlington, VA: Association of Official Analytical Chemists.

AOAC. 2012. Official methods of analysis of AOAC International 19th Ed. Association of Official Analytical Chemists, Gaithorsburg Maryland.

Arslan, S. and S. Özel. 2012. Some properties of stirred yoghurt made with processed grape seed powder, carrot juice or a mixture of grape seed powder and carrot juice. Milchwissenschaf. 67: 281-285.

Bae, E.K. and S.J. Lee. 2008. Microencapsulation of avocado oil by spray drying using whey protein and maltodextrin. J. of Microencapsulation. 25 (8):549-560.

Bule, M.V., R.S.Singhal and J.F.Kennedy. 2010. Microencapsulation of ubiquinone-10 in carbohydrate matrices for improve stability. Carbohydrate Polymers. 82 (1):1290-1296.

Carneiro, H.C.F., R.V.Tonon, C. R.F. Grosso and M. D. Hubinger. 2013. Encapsulation efficiency and oxidative stability of flaxseed oil microencapsulated by spray drying using different combinations of wall materials. J. of Food Engineering. 115:443-451.

Charoen, R., A. Jangchud, K. Jangchud, T. Harnsilawat, O. Naivikul and D. J. McClements. 2011. Influence of biopolymer emulsifier type on formation and stability of rice bran oil-in water emulsions : Whey protein, gumarabic, and modified starch. J. Food Sci. 76: 165-172. 
Chen, C., Y. Yang, C.Shen, S.Lai, C.J.Chang and C.Shieh. 2011. Recovery of vitamins B from supercritical carbon dioxide defatted rice bran powder using ultrasound water extraction. J. Taiwan Inst. Chem. Eng. 42:124-128.

Chou, T. W., C. Y.Ma, H. H.Cheng, Y. Y.Chen and M. H. Lai. 2009. A rice bran oil diet improves lipid abnormalities and suppress hyperinsulinemic responses in rats with streptozotocin/nicotinamide-induced type 2 diabetes. J. of Clinical Biochemistry and Nutrition. 45:29-36.

Devarajan, S., R.Singh, B.Chatterjee, B.Zhang and A.Ali. 2016 b. A blend of sesame oil and rice bran oil lowers blood pressure and improves the lipid profile in mild-tomoderate hypertensive patients. J. of Clinical Lipidology. 10:339-349.

Dickinson, E. and Y.Matsumura. 1991. Time-dependent polymerization of $\beta$-lactoglobulin through disulphide bonds at the oil-water interface in emulsions. International J. of Biological Macromolecules. 13 (1):26-30.

EEC. 1991. Characteristics of olive and olive pomace oils and their analytical methods. Regulation EC/2568/91 and latter modification. Official J. of the European communities.

El-Abbadi, N.H., M.C. Dao and S.N. Meydani. 2014. Yogurt: role in healthy and active aging. Am. J. Clin. Nutr. 99(5):1263S-1270S.

Gharsallaoui, A., G.Roudaut, L.Beney, O.Chambin, A.Voilley and R. Saurel. 2012. Properties of spray-dried food flavours microen-capsulated with two-layeredmembranes: roles of interfacial interac-tions and water. Food Chemistry. 132(4):1713-1720.

Gharsallaoui, A., G.Roudaut, O.Chambin, A.Voilley and R.Saurel. 2007. Applications of spray-drying in microencapsulation of food ingredients: an overview. Food Research International. 40(9):1107-1121.

Gopala Krishna, A., K. H.Hemakumar and S. Khatoon. 2006. Study on the composition of rice bran oil and its higher free fatty acids value. J. of the American Oil Chemists' Society. 83:117-120.

Gutfinger, T. 1981. Polyphenols in olive oils. J.A.O.C.S., 61 (9): 966-968.

Herald, T. J., F. M. Aramouni and M. H. Abu- Ghoush. 2008 Comparison Study of Egg Yolks and Egg Alternatives in French Vanilla Ice Cream. J. Texture Stud. 39: 284- 295.

IOOC. 2001. Method of analysis of the International olive oil Council preparation of the fatty acid methyl esters from olive oil and olive pomace oil. Co, T. 20:24.

Jafari, S.M., E.Assadpoor, B.Bhandari and Y. He. 2008 b. Nano-particle encapsulation of fish oil by spray drying. Food Research International. 41(2):172-183.

Juttulapa, M., S. Piriyaprasarth, H. Takeuchi and P. Sriamornsak. 2017. Effect of high-pressure homogenization on stability of emulsions containing zein and pectin. Asian J. of Pharmaceutical Sci. 12: 21-27.

Kim, H.J., S.B.Lee, K.A.Park and I.K. Hong. 1999. Characterization of extraction and separation of rice bran oil rich in EFA using SFE process. Sep Purif Technol. $15: 1-8$.
Krishnan, S., R. Bhosale and R. Singhal. 2005. Microencapsulation of cardamom oleoresin: evaluation of blends of gum arabic, maltodextrin and a modified starch as wall materials. Carbohydr Polym. 61(1):95-102.

Lee, Y.C., S.W.Oh, J.Chang and I.H. Kim. 2004. Chemical Composition and Oxidative Stability of Safflower Oil Prepared from Safflower Seed Roasted with Different Temperatures. Food Chemistry. 84:1-6.

Li, Y. and D. Xiang. 2019. Stability of oil-in-water emulsions performed by ultrasound power or high-pressure homogenization. PLOS ONE. 14(3): e0213189.

Lucey, J.A. 2001. The relationship between rheological parameters and whey separation in milk gels. Food Hydrocolloids. 15(4-6): 603-608.

Mendez, E., J. Sanhueza, H. Speisky and A. Valenzuela. 1997. Comparison of Rancimat evaluation methods to assess oxidative stability of fish oil. J.A.O.C.S. 79(3): 331-332.

Millqvist-Fureby, A. 2003. Characterisation of spray-dried emulsions with mixed fat phases. Colloids Surf B. 31(14):65-79.

Mosquora, M.M.L., N.L. Rejano, R.B. Gandul, G.A. Sanchez and F.J. Garrido. 1991. Color pigments correlation in virgin olive oil. J.A.O.C.S. 68:332-336.

Oh, D.H., P.Balakrishnan, Y.K.Oh and D.Kim. 2011. Effect of process parameters on nanoemulsion droplet size and distribution in SPG membrane emulsification. International J. of Pharmaceutics. 404 (1-2):191-197.

Rao, Y. P., P. P.Kumar and B. R. Lokesh. 2016. Molecular mechanisms for themodulation of selected inflammatory markers by dietary rice bran oil in rats fed partially hydrogenated vegetable fat.Lipids. 51:451-467.

Rodea-González, D. A., J.Cruz-Olivares, A.Román-Guerrero, M. Rodríguez-Huezo, E. J.Vernon-Carter, C.PérezAlonso. 2012. Spray-dried encapsulation of chia essential oil (Salvia hispanica L.) in whey protein concentratepolysaccharide matrices.J. Food Eng. 111: 102: 109.

Saint-Eve, A., C. Lévy, N. Martin and I. Souchon. 2006. Influence of proteins on the perception of flavored stirred yogurts. J. Dairy Sci. 89(3):922-933.

Sanchez, C.M., M.Berjano and C.G. Guerrero. 2001. Emulsification rheokinetics of nonionic surfactantstabilized oil-in-water emulsions, Am. Chem. Soc. 17: 5410-5416.

SAS. 1994. SAS user's: Statistics. SAS institute Inc, cary, NC., USA.

Serra, M., A.J. Trujillo, B. Guamis and V.Ferragut. 2009. Evaluation of physical properties during storage of set and stirred yogurts made from ultra-high pressure homogenization-treated milk.Food Hydrocolloids.23(1): 82-91.

Surh, J. H., G. T. Vladisavljevic, S. H. Mun and D. J. McClements. 2007. Preparation and Characterization of water/oil and water/oil/water emulsions containing biopolymergelled water droplets. J. Agric. Food Chem. 55: 175-184.

Tamjidi, F., A.Nasirpour and M.Shahed. 2012. Physicochemical and sensory properties of yogurt enriched with microencapsulated fish oil. Food Sci. and Technology International. 18(4): 381-390. 
Tomar, S.K., D.N. Prasad. 1987. Effect of pre-heat treatment on microstrucutre of cow whole milk yoghurt as revealed by scanning electron microscopy. Microbiol Aliments Nurtr. 5:345-350.

Ustun, G., L. Kent, N. Cekin, H.Civelekoglu. 1990. Investigation of the technological properties of N. sativa (black cumin) seed oil. Am. Oil Chem. Soc. 67:958-960.
Wilson, T.A., L.M.Ausman, C.W.Lawton, D.M.Hegsted, R.J.Nicolosi. 2000. Comparative cholesterol lowering properties of vegetable oils: beyond fatty acids. J. Am. Coll. Nutr. 19(5):601- 607.

Wong, M.L., R.E. Timms and E.M. Cioh. 1988. Colorimetric determination of total tocopherols in palm oil, olein and stearin. J.A.O.C.S. (2): 258-261.

\section{الملخص العربي}

\section{كبسلة زبت رجيع الكون بواسطة التجفيف بالرزاز واستخدامه فى إنتاج زبادى عالى الجودة}

ناهد محمد محروس عطا1 ،أحمد محمد أبوخشبه1، أميمه السيد شلتوت22، هشام عبداللطيف عبد الحليم33 ،

$$
\text { إنتصار عبدالمحسن الدفراوى }
$$

التوليفة في كبسلة زيت رجيع الكون سبب انخفاض في محتوى الزيت السطحي (0.22) وزيادة في كفاءة الكبسلة (\%78) شقوق أو تشققات مع زوائد صغيرة من الحبيبات المكبسلة باستخدام الخليط السابق من مواد الجدار مع اختلاف نسب اضافة الزيت إليه (2:1 و 4:1). أدى اضافة تركيزات مختلفة من مسحوق زيت رجيع الكون المكبسل (2و 4و 6\%) وكذلك اضافة زيت رجيع الكون في صورته الحرة (2\%) إلى عينات من الزبادي انخفاض قيمة الأس رجيع

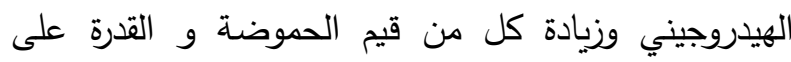
الاحتفاظ بالماء طوال فترات التخزين. وفقا للنتائج المتحصل عليها، حدثت تغيرات في الخواص الحسية لعينات زبادي الكنترول والمدعمة بزيت رجيع الكون بصورتيه سواء الحرة

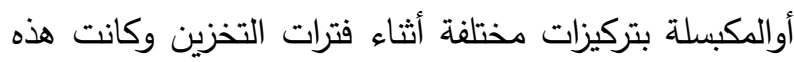

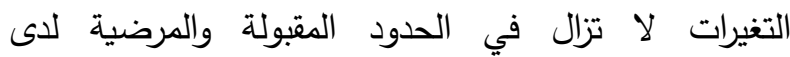

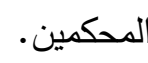

تم كبسلة الزيت المستخلص من رجيع الكون كمنتج ثانوي بواسطة المكبس الهيدروليكي عن طريق التجفيف بالرزاز باستخدام مواد التغليف (المالتودكسترين و مركزات شرش اللبن والصمغ العربي) بنسب (0:2:3 و 1:1:3 و 2:0:3) على التوالي وكانت النسبة بين اضافة الزيت كمادة نواة إلى مواد الجدار (2:1 و 4:1). تم تقييم الثبات وتوزيع حجم الحبيبات وكذلك الثحنة السطحية للمستحلب الناتج كما تمت دراسة كفاءة التغليف والثكل المورفولوجي لمساحيق ولت الكبسولات الناتجة. ثم تم تدعيم الزبادي بزيت رجيع الكون الحر والمكبسل وتقدير الخواص الفيزيائية والكيميائية وكذلك بلك

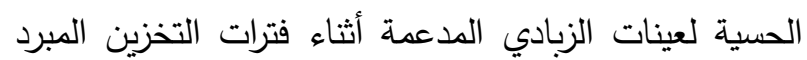
عند صفر و 7 و 14 يوم. أوضحت الدراسة أن للتوليفة المكونه من خليط مواد التغليف (المالتودكسترين 3: الصمغ ون العربي2) ونسبة الزيت لهذا الخليط (4:1) أعلى فاعلية على ثبات المستحلب (100\%) بدون حدوث فصل وتوزيع حجم الحبيبات ( 249.8 نانومتر) وأيضا الثحنة السطحية للمستحلب (-31.49 مللى فولت). وأن استخدام نفس 